\title{
THE REAPPEARANCE OF THE SUPRA-PROVINCIAL COMMANDS IN THE LATE SECOND AND \\ EARLY THIRD GENTURIES C.E.: CONSTITUTIONAL AND HISTORICAL CONSIDERATIONS
}

\author{
FREDERIK J. Vervaet
}

\begin{abstract}
Introduction
This paper aims at examining and explaining the nature of some spectacular extraordinary commands from the reign of Marcus Aurelius to the reign of Philippus Arabs (161-249 C.E.). Although the initial plan was to focus primarily on the third century proper, the period between the reigns of Philippus Arabs (244-249) and Diocletian (284-305) is so chaotic that it becomes very hard to distinguish between the ordinary and the exceptional. After a brief definition of what will be considered an extraordinary command in this paper, we will first have to survey a number of relevant precedents from the preceding centuries. Indeed, the extant source material for the attested extraordinary commands from the period discussed is so limited that this gradual approach is the only means to develop a number of plausible explanations concerning the commands scrutinized in this paper, namely those held by C. Avidius Cassius in 169-175 and by C. Iulius Priscus in 244-249.
\end{abstract}

\section{A matter of definition}

Under the Empire, the only official distinction between provincial commanders was that between the governors of the public provinces, on the one hand, and the governors of the provinciae Caesaris, on the other hand. Whereas the first category of governors were all praetorians or consulars and all carried the title of proconsul, the rank and official titles of the latter category varied greatly. All but one of the most important imperial provinces were governed by praetorian or consular officials who held the title of legatus Augusti pro praetore. The key position of praefectus Aegypti and the ever increasing number of procuratorships, both 
gubernatorial and financial, however, were the exclusive reserve of the equestrian order.

It is important to ascertain that there never existed such thing as an officially designated extraordinary command under the Empire. Nonetheless, it did occasionally happen that commands were created outside of the regular order, both in terms of geographical scope and powers granted. In this paper, we will focus primarily upon what one could perhaps best define as supra-provincial commands, commands which involved the superimposition of one commander-in-chief upon the existing administrations of a well-defined number of regular provinces. As the Emperor was legally entitled to freely dispose of his share of the provinces, multi-provincial commands involving the temporary union of certain imperial provinces under the command of a single governor were not that unique. ${ }^{1}$ This means that, for example, the commands of Sextus Sentius Caecilianus (suff. ca. 76), who was legatus Augusti pro praetore ordinandae utriusque Mauretaniae in 75 and as such replaced the procurators who normally governed both Mauretanias, ${ }^{2}$ or M. Cornelius Fronto (suff. 165), who held the position of legatus Aug(g.) pro praetore trium Daciarum et Moesiae Superioris in 169/170, ${ }^{3}$ will not be given any further consideration, however spectacular their positions. Of those of the above-defined supra-provincial commands, special attention will be given to the ones comprising both imperial and public provinces, as the Senate was at least theoretically entitled to have its say in their admin-

${ }^{1}$ Within what he termed the "Multi-Provincial Commands in the Roman Empire", D. Potter, 'Palmyra and Rome: Odaenathus' Titulature and the Use of the Imperium Maius', Zeitschrift fuir Papyrologie und Epigraphik 113 (1996), 274f., was the first to draw a distinction between commands involving the combination of two or more provinces "into a 'joint province' that was governed by one man" and those involving "a grant of superior imperium to an individual so that he could give orders to provincial governors within a specified region". Potter rightly explains that "Previous studies of extraordinary governorships have tended to group governors of 'double provinces' with holders of imperium who were empowered to give instructions in provinces that had regularly appointed governors of their own. I have separated the two groups, as I believe that the two phenomena are distinct." Strangely enough, however, Potter still lumps together both indeed fundamentally different categories of commands under the label of 'multi-provincial commands'. For clarity's sake, it is, perhaps, better to clearly distinguish between, on the one hand, multi-provincial commands established through the provisory union of two or more provinces under the command of a single governor, and, on the other hand, supra-provincial ones, which assigned the supervision of two or more normally independent provincial administrations to one commander-in-chief.

${ }^{2} A E$ 1941, no. 79.

${ }^{3}$ ILS 1097 and 1098; cf. also 2311. 
istration. This means that as far as the period from 161 to 249 C.E. is concerned, we will primarily discuss the commands of C. Avidius Cassius and C. Iulius Priscus.

\section{The supra-provincial commands of the Early Empire: a brief survey}

A first category of early imperial supra-provincial commands regards the relatively well-known extraordinary proconsulships from the reigns of Augustus and Tiberius. As is quite clear from the literary and epigraphic sources, men like Agrippa, Drusus and Tiberius, Gaius Caesar, Germanicus and Drusus Minor were granted proconsulships extra ordinem, outside of the regular, annual appointments of proconsuls for the administration of the public provinces. Their commands were created ex auctoritate principis, at the formal behest of the Emperor, by virtue of a decree of the Senate and a subsequent popular law, and generally lasted for five consecutive years (in quinquennium). Whereas the constitutive laws probably only concerned the genus and relative strength of the imperium and its duration, it were Prince and Senate who defined and redefined the specific tasks and geographical scope of the proconsuls involved. In 23 B.C.E., for example, Agrippa (in all likelihood) received a five-year consulare imperium and spent part of his tenure in the East. ${ }^{4}$ In 18 and 13 B.G.E. respectively, Agrippa was given two more terms, his consulare imperium being redefined as maius with respect to that of the regular proconsuls in the final instance. ${ }^{5}$ In 17 G.E., Senate and People redefined Germanicus' extraordinary proconsulship in that he was charged with the administration of all the lands from the Ionian coast to the borders of Egypt, his consulare imperium being now legally maius with respect to the proconsuls of the public provinces. ${ }^{6}$ In my opinion, Tacitus' Annales 2.59 unequivocally shows that Germanicus was not legally entitled to enter Egypt without formal and explicit authorization on the part of Tiberius. After the reign of Tiberius, however, the conferral of

${ }^{4}$ Dio Cassius 53.31.1 and Josephus, Antiquitates Fudaicae 15.350.

${ }^{5}$ Dio Cassius 54.12.4f. (18 B.C.E.) and 54.28.1 (13 B.C.E.).

${ }^{6}$ See W. Eck, A. Caballos and F. Fernández, Das senatus consultum de Cn. Pisone patre (München 1996), 40 (comments on pp. 157-162) and Tacitus, Annales 2.43.1; Josephus, Antiquitates Fudaicae 18.54; Velleius Paterculus 2.129.3 and Suetonius, Caligula 1.2. For the quinquennial duration of these special proconsulships, see F. Hurlet, 'Recherches sur la durée de l'imperium des "co-régents" sous les principats d'Auguste et de Tibère', Cahiers du Centre Gustave Glotz 5 (1994), 255-289. 
such extraordinary proconsulships was limited to crown princes only, just as was the case with the tribunicia potestas. With the exception of, for example, Aelius Caesar's stay in Pannonia in 136/137, most of these Imperators-designate would stay in Rome to assist the Emperor in his administration of City and Empire.

This momentous evolution did not mean, however, that the practice of granting supra-provincial commands ceased to exist altogether. Domitius Corbulo's spectacular career in the Eastern provinces offers a first interesting example. Although Corbulo (suff. 39) had already governed the 'multi-provincial' complex of Cappadocia-Galatia (with Pamphylia) from 54/55 to 60, when Syria too was briefly added to his already vast gubernatorial responsibilities, it is especially the redefinition of his official position in the spring of 63 that is of real interest to this inquiry. After the humiliating defeat of L. Iunius Caesennius Paetus (ord. 61), who had been sent in 61 to relieve Corbulo of the command of Cappadocia-Galatia, Nero and his counsels decided to make a rather spectacular arrangement, accurately summarized in Tacitus' Annales 15.25.3. Tacitus here records that

Syriaeque exsecutio C. Cestio, copiae militares Corbuloni permissae; et quinta decuma legio, ducente Mario Celso e Pannonia, adiecta est. Scribitur tetrarchis ac regibus praefectisque et procuratoribus et qui praetorum finitimas provincias regebant iussis Corbulonis obsequi, in tantum ferme modum aucta potestate quem populus Romanus Cn. Pompeio bellum piraticum gesturo dederat.

The administration of Syria was entrusted upon C. Cestius, the military forces to Corbulo, with the addition of the fifteenth legion from Pannonia under the command of Marius Celsus. Instructions in writing were given to the tetrarchs, kings and prefects, and the procurators and the praetors in charge of the neighbouring provinces, to take their orders from Corbulo, whose powers were raised to nearly the same level as that given by the Roman People to Pompey for the conduct of the pirate war.

As is clear from Tacitus' summary and other indications in the sources, Corbulo reassumed the command of Cappadocia-Galatia, whereas Syria was now assigned to C. Cestius Gallus (suff. 42), on the condition, however, that Corbulo retained the command of the Syrian legions, whereas Gallus was to busy himself with Syria's cumbersome civil administration. Nero furthermore instructed all of the native tetrarchs, kings and prefects and the Roman procurators and those legati Augusti pro praetore who governed the provinces neighbouring Cappadocia-Galatia to obey Corbulo's orders.

In my opinion, three important observations can be made. First, Tacitus' account strongly suggests that it was Nero who made these 
arrangements, a decree of the Senate being technically unnecessary as all territories concerned were part of Caesar's vast provincial dominion. Next, it is important to emphasize that Corbulo was given no new imperium whatsoever. As legatus Augusti pro praetore Corbulo simply continued to wield delegated praetorium imperium. Neither was this existing imperium made officially maius with respect to that of his fellow legati Augusti pro praetore, as the consular and praetorian legati Augusti pro praetore of Syria and Lycia-Pamphylia and all other official authorities in the Eastern part of the imperial provinces were instructed to obey his commands by virtue of imperial mandata. ${ }^{7}$ All of this means that Corbulo's command of 63 was very different from that of, for example, Germanicus. The latter as proconsul held independent consular imperium and owed his office and supra-provincial powers to votes of Senate and People respectively, passed at the behest of the Emperor. Germanicus' consulare imperium was, moreover, redefined as maius quam with respect to that of the proconsuls governing the public provinces that fell within the official confines of his supra-provincial command. ${ }^{8}$

\section{Pliny's extraordinary command in Pontus-Bithynia}

Before discussing the supra-provincial commands of the late second and early third centuries C.E., it is useful to briefly highlight the equally interesting command of C. Plinius Caecilius Secundus (suff. 100) in Pontus-Bithynia, generally dated around $110-112$ C.E. ${ }^{9}$ Although this

${ }^{7}$ ILS 232. Cf. Tacitus, Annales 15.17 .2 for the fact that legati Augusti pro praetore were strictly tied to their imperial mandata.

${ }^{8}$ See F.J. Vervaet, 'Tacitus Ann. 15.25.3: A revision of Corbulo's imperium maius (A.D. 63-A.D. 65?)', in C. Deroux (ed.), Studies in Latin Literature and Roman History, Volume X (Brussels 2000) 260-298 for a full discussion of Corbulo's command from 63 to 66. The generally accepted though mistaken view that Corbulo was granted "imperium maius über den ganzen Nahen Osten" was recently reiterated by C. Körner, Philippus Arabs. Ein Soldatenkaiser in der Tradition des antoninisch-severischen Prinzipats (Berlin and New York 2002), 60. Although Tacitus also styles the praetorian proconsul of Bithynia as praetor in Annales 1.74, he makes no mention whatsoever of the involvement of a public province in his remarkably complete summary of the measures taken in the spring of 63. Besides, the submission of a proconsul to Corbulo would have required a decree of the Senate. As in 67, Cn. Pompeius, too, had been officially empowered to draw the necessary funds from provincial authorities and was put in charge of a (far more impressive) series of legati pro praetore, Tacitus' aggrandizing statement that Corbulo's enhanced mandate recalled that of Pompeius against the pirates is not totally unfounded.

${ }^{9}$ For the abundant bibliography on the question of the exact chronology of Pliny's legateship in Pontus-Bithynia, see G. Alföldy, 'Die Inschriften des jüngeren Pliny und 
public province was at the time normally governed by proconsuls of praetorian standing, CIL 5.5262 (Comum) records that Pliny administrated it as legatus Augusti pro praetore consulari potestate, and this ex senatus consulto missus ab Imperatore Caesare Nerva Traiano. ${ }^{10}$ In other words, Pliny was sent to govern Pontus-Bithynia by decree of the Senate and in the capacity of legatus Augusti pro praetore with consular imperium.

Pliny's unprecedented position involves several remarkable oddities. ${ }^{11}$ Rather than having him appointed to an extraordinary proconsulship, which would have involved a formal vote of the People, the Emperor chose to work through the Senate. There is every indication that, evidently on the Emperor's own motion, the Senate authorized him to send Pliny as an imperial legate to Pontus-Bithynia, and at once decreed that he should administer this province consulari potestate. ${ }^{12}$ As for the reason of this grant of consular imperium to an imperial legate invested with the administration of a public province, one might, at first sight, be tempted to argue that Pliny was given postestas consularis to buttress his official position vis-à-vis those regular staff members in the public provinces who also carried delegated praetorium imperium, to wit the quaestor and the legatus proconsulis. However, Trajan and the Senate could have perfectly ordered all regular staff in the province to stay in office and obey Pliny' every command without upgrading his imperium, as Nero had done before in the case of Corbulo. Besides, as the Emperor's appointee

seine Mission in Pontus et Bithynia', in Idem, Städte, Eliten und Gesellschaft in der Gallia Cisalpina. Epigraphisch-historische Untersuchungen (Stuttgart 1999), 221 n. 4.

${ }^{10}$ Cf. also the fragmentary inscription published in CIL 6.1552 $=11.5272$ (Hispellum). In my opinion, Th. Mommsen's readings of both texts are still to be preferred over those of E. Bormann and G. Alföldy, who argue that Pliny was sent into the province proconsulari potestate. The term proconsulare imperium, however, only surfaces in literary sources from the reign of Tiberius, and is (to the best of my knowledge) not documented elsewhere by epigraphy. In my opinion, such references as Tacitus, Annales 2.56.4, 2.71.1 (cf. Cicero, In Catilinam 3.15) and 14.18.2; Tacitus, Historiae 4.3.3 and Suetonius, Domitianus 1 (Domitianus as praetor urbanus with consulare imperium); and Scriptores Historiae Augustae, Vita Aemiliani 22.10 and Vita Probi 13.1 strongly suggest that, in terms of public law, the imperium of imperial legati pro praetore and proconsuls remained the praetorium and consulare imperium respectively. Ultimately, however, the question whether Pliny was sent consulari potestate or proconsulari potestate is irrelevant to the argument of this paper.

${ }_{11}$ Alföldy 1999, op. cit. (n. 9), 236, rightly emphasizes that Pliny's mission (and position) was wholly unprecedented.

${ }_{12}$ To some extent, this upgrade of imperium reminds of the Republican practice of the praetura pro consule. 
would govern the province instead of the regular proconsul, ${ }^{13}$ it is quite possible that the Senate equally authorized him to appoint Pliny's quaestor and legates. As a legate wielding merely delegated imperium, Pliny could not normally have done so himself without explicit authorization. In light of G. Alföldy's conclusive demonstration that Pliny's mission was a provisional imperial interference in what continued to be a public province, ${ }^{14}$ it is, however, far more likely that the arrangement was made out of consideration for the Senate and the existing administrative division between public and imperial provinces. As the first category of provinces was regularly governed by officials with consulare imperium, official propriety dictated that the Emperor's man in the public province should be given all of the proconsul's regular potestas and insignia. ${ }^{15}$ Since Pliny was of consular rank at the time of his extraordinary mission in PontusBithynia, it should, moreover, not be doubted that he was escorted by twelve lictors. ${ }^{16}$ The fact that Pliny surpassed the regular (praetorian) proconsul of Pontus-Bithynia in terms of both senatorial rank and outward trappings would obviously further boost his authority and prestige

${ }^{13}$ See Mommsen's reconstruction of CIL 6.1552 $=11.5272$ : ex s(enatus) c(onsulto) pro/[co(n)s(ulis) loco in prouincia Ponto] et Bithynia et legatus / [pro pr. Imp. Traiani Aug. prouinciae eiusdem] in Gesammelte Schriften 4 (Berlin 1906), 443-446. In Alföldy's reconstruction of the text (1999, op. cit. (n. 9), 234) the term legatus figures twice, which seems to be rather unlikely. Mommsen's suggested reading has the advantage of summarizing precisely what happened: Pliny being sent to Pontus-Bithynia instead of a proconsul by decree of the Senate and as legatus Augusti pro praetore.

${ }_{14}$ Alföldy 1999, op. cit. (n. 9), 237. Alföldy, loc. cit. (and especially 237 n. 38) is right to suggest that it is most likely that C. Iulius Cornutus Tertullus, who governed Pontus-Bithynia as legatus Augusti pro praetore from ca. 112 to ca. 115 (CIL 14.2925 = ILS 1024) as Pliny's immediate successor was also granted the same enhanced power.

${ }^{15}$ Compare P. Eich, 'Proconsulis appellatio specialis est' (review article of E. Meyer-

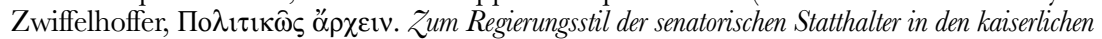
griechischen Provinzen, Stuttgart 2002), Scripta Classica Israelica 23 (2004), 237: "Die plausibelste Deutung dieser Titulatur ist die, daß Plinius die gleichen Rechte wie Proconsuln hatte, gleichzeitig aber kaiserlicher Legat war." Eich also makes the plausible suggestion that this arrangement "stellte ein zusätsliches Element der Legitimation dar und sollte vielleicht seine Autorität in der krisengeschüttelten Provinz stärken."

${ }^{16}$ Correctly so H.M. Cotton, 'Cassius Dio, Mommsen and the quinquefascales', Chiron 30 (2000), 234. See Dio Cassius 53.13.4 and 8 for the fact that from 27 B.C.E., only consular proconsuls were entitled to twelve lictors, whereas their praetorian colleagues had only six. Regardless of their senatorial rank, all legati Augusti pro praetore alike employed only five lictors. Contra A.N. Sherwin White, The Letters of Pliny. A Historical and Social Commentary (Oxford 1966), 81f. and Alföldy 1999, op. cit. (n. 9), 240, who claim that Pliny was given only six lictors, just like the praetorian proconsuls he replaced. Alföldy further wrongly suggests that all holders of proconsularis potestas received six lictors, whereas only holders of consularis potestas were entitled to twelve. 
within the troubled province. The importance of his mission perfectly accounts for this additional deviation from customary practice.

Pliny's official title presents another particularity: rather than being dispatched as legatus Augusti pro consule, he still retained the traditional title of legatus Augusti pro praetore, regardless of the formal upgrade of his imperium. There are various ways to explain this remarkable decision. T.C. Brennan recently argued that imperium could only be delegated at the level of praetorium imperium, grants of derived consular imperium being legally impossible. ${ }^{17}$ Although this indeed seems to have been the rule for the Republic, Trajan was definitely not the man to flinch from such a constitutional innovation, the more so as he did venture to send Pliny to a public province with an unprecedented title. In my opinion, this arrangement powerfully demonstrates that the official titles of the governors of the respective categories of provinces were increasingly becoming generic denominations. At any rate, Pliny's appointment and entitlement was a significant step towards the dissociation of official title and actual powers held by the official involved. The arrangement also was an important forerunner of the dissolution of the Augustan provincial settlement.

The extraordinary commands from Marcus Aurelius to Philippus Arabs

After this preliminary survey we can now proceed to the most important section of this contribution, the discussion of the supra-provincial commands of C. Avidius Cassius (suff. 166?) and C. Iulius Priscus. Probably in 166 C.E., in the immediate aftermath of the Parthian war, M. Aurelius and Lucius Verus put Avidius Cassius in charge of Syria as consular legatus Augg. pro praetore. ${ }^{18}$ Probably shortly after the untimely death of L. Verus in 169, Cassius was invested with the supreme command of all provinces past the Aegean Sea, as Dio Cassius records in 71.3.12 that,

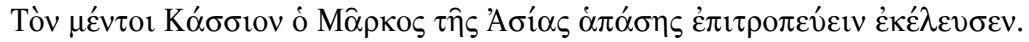

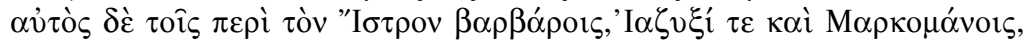

17 T.G. Brennan, The Praetorship in the Roman Republic (Oxford 2000), 36f. (cf. also 642 and 647). In my opinion, Brennan's suggestion that only holders of consular imperium could delegate praetorium imperium is rather doubtful.

${ }^{18}$ In the epigraphic records of his tenure as governor of Syria (IGRR 3.1261 and

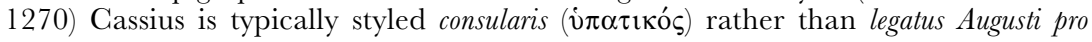
praetore. 


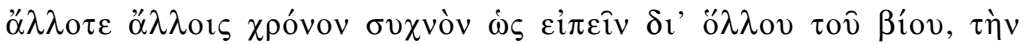

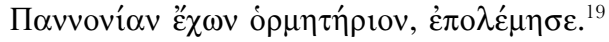

Cassius, however, was ordered by Marcus to have charge of all Asia. The emperor himself fought for a long time, in fact, almost his entire life, one might say, with the barbarians in the region of the Ister, with both the Iazyges and the Marcomanni, one after the other, using Pannonia as his base.

Even though there is no further relevant source material on Cassius' official position until his enigmatic rebellion and death in 175 , it may still be possible to formulate some plausible hypotheses about his extraordinary command. Since Cassius' extended power sphere at any rate comprised the public province of Asia, the arrangement must have involved a vote of the Senate. On the analogy of what was decided with regard to Pliny's position in Pontus-Bithynia around 110, the Senate may have raised Cassius' imperium to consular, as it would have been wholly inappropriate to subordinate the consular proconsul of Asia to the command of a legate holding merely praetorian imperium and carrying only five fasces. In terms of both public law and senatorial propriety, such an arrangement would have made no sense at all. Although it is generally believed that Cassius was granted maius imperium throughout the Eastern Empire, ${ }^{20}$ there is no indication whatsoever that he was ever given independent imperium. ${ }^{21}$ Therefore, it is perhaps better to assume that the Senate and the Emperor instructed all other officials in the Eastern provinces to obey Cassius' commands, mutatis mutandis on the model of the arrangement made more than a century ago on behalf of Domitius Corbulo. Last but not least, the fact that, probably in 172 C.E., Marcus Aurelius ordered Avidius Cassius to quell a major revolt in Egypt strongly suggests that this key province did not fall within his enlarged

19 Translation and numbering of the text passage as in the Loeb edition. Cf. also

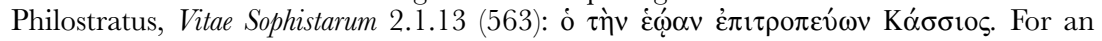
elaborate discussion of Cassius' meteoric career from the Parthian war up to the conferral of his supra-provincial command, see especially M.L. Astarita, Avidio Cassio (Roma 1983), 39-59.

${ }^{20}$ Cf. Astarita 1983, op. cit. (n. 19), 56-58 and 86 and, more recently, D. Potter 1996, op. cit. (n. 1), 280f. Potter (loc. cit., cf. also p. 274) is equally wrong to suggest that Avidius Cassius was given "the post of corrector in the east".

${ }^{21}$ All recorded instances of (proposed) grants of (conditional) consulare imperium maius quam concern holders of independent imperium auspiciumque: Cn. Pompeius in 57 B.C.E. (motion defeated), Cassius Longinus in 43 B.C.E. (motion defeated), Augustus in 23 B.C.E., Agrippa in 13 B.G.E. and Germanicus in 17 C.E. 
sphere of command. ${ }^{22}$ In this respect only, his supra-provincial command did resemble that of Germanicus, who had to supervise more or less the same geographical area.

At all events, the spectacular redefinition of Cassius' position in 169 is another signal indicator of the progressive erosion of the Augustan distinction between public and imperial provinces and the traditional titles of proconsul and legatus Augusti pro praetore. It was unprecedented that public and imperial provinces alike were put under the command of an official appointed directly by the Emperor. Although it should not be doubted that Marcus Aurelius did scrupulously involve the Senate in his decision to appoint a kind of imperial Viceroy in the East, the arrangement underscores the growing imperial preference for drastic interference in the public provinces.

Finally, an inscription from Timgad from 247-249 records that C. Iulius Priscus, brother of Philippus Arabs (244-249), held the otherwise unknown position of rector Orientis. ${ }^{23}$ Apart from this, there is every indication that Priscus probably held the praefectura praetorio twice, a first time still before the accession of his brother and then again during the later part of the latter's reign, and that he held the both epigraphically and papyrologically attested office of praefectus Mesopotamiae, probably in between his two tenures as prefect of the Guard. ${ }^{24}$ At all events, it is beyond all doubt that he owed the position of rector Orientis to his brother as Emperor. The same papyrus from 245 that records his prefecture of

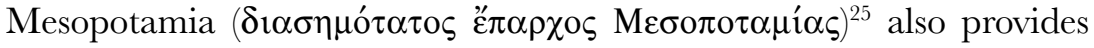
important further clues as to the precise nature of his official position in the East, since it also attests him as administering justice from Antiochia (where he resided for at least one period of eight months) as $\delta i \varepsilon ́ \pi \omega v$

${ }^{22}$ For the revolt of the so-called Bucoli and its ruthless suppression, see Dio Cassius 72.4. H. Halfmann, Die Senatoren aus dem östlichen Teil des Imperium Romanum bis zum Ende des 2. Fahrhunderts n. Chr. (Göttingen 1979), 179, rightly indicates that Dio Cassius'

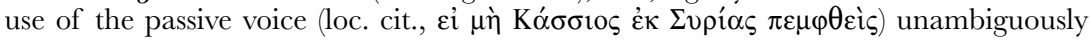
suggests that Cassius received orders to interfere in Egypt from Syria, and that those mandata can only have been issued by Marcus Aurelius. Therefore, Astarita 1983, op. cit. (n. 19), 86f., is wrong to suggests that Cassius' enhanced powers enabled him to interfere in Egypt as he saw fit, and that he entered the province either at the invitation of the praefectus Aegypti or at his own discretion. Astarita, loc. cit., is equally mistaken to believe that "dopo il precedente di Germanico, il problema [of a senator entering Egypt] non si pone piư". Halfmann, loc. cit., however, is equally wrong to argue that Avidius Cassius was only put in charge of Syria and Arabia in 169/170.

${ }^{23}$ CIL $3.14149^{5}=$ ILS 9005 .

${ }^{24}$ See Körner 2002, op. cit. (n. 8), 55-57.

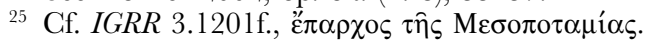


$\tau \grave{\eta} v \dot{v} \pi \alpha \tau \varepsilon i \alpha v$, i.e., "holder of the highest office" ${ }^{26}$ On the basis of this papyrus, some scholars are inclined to identify this second office with that of rector Orientis. ${ }^{27}$ Most scholars, however, believe that he exceptionally combined two regular governorships, viz. the strategically important equestrian prefecture of Mesopotamia, on the one hand, and Syria Coele, normally governed by consular legati Augusti pro praetore, on the other hand. ${ }^{28}$ According to C. Körner, who adheres to the second view and even suggests that Priscus also directly assumed the governorship of other provinces, the title of rector Orientis "sollte zum Ausdruck bringen, dass Priscus mehrere Statthalterschaften gleichzeitig ausübte". ${ }^{29}$

As M. Peachin, however, rightly points out that there were several governors of Syria precisely during Priscus' term as rector Orientis, ${ }^{30}$ the most plausible reconstruction of the command structure in the East seems to be the following one. When Philippus Arabs came to power in 244, he not only appointed his brother to the at that time key office of praefectus Mesopotamiae, but also decided to entrust him with the high command in the entire East. To that means, he invested his brother with the unprecedented office of rector Orientis. As Zosimus records that Philippus Arabs entrusted him with the command of the armies in Syria and

${ }^{26}$ Pap. Euphr. 1, ll. 3 and 19f. - first published by D. Feissel and J. Gascou, 'Documents d'archives romains inédits du Moyen Euphrate (III ${ }^{\mathrm{e}}$ siècle après J.-C.)', Comptes rendus de l'Académie des Inscriptions et Belles-Lettres (1989), 545-557; and then again by the same authors in 'Documents d'archives romains inédits du Moyen Euphrate (III ${ }^{\mathrm{e}}$ siècle après J.-C.): I. Les petitions (Pap. Euphr. 1 à 5)', Fournal des Savants (1995), 67-84. In my opinion, "holder of the highest office" should be preferred over Körner's suggestions (2002, op. cit. [n. 8], 58 + n. 186): "zu übersetzen mit 'den Konsulat oder eine konsulare Statthaltershaft" and "Vielmehr bezeichnet $\dot{v} \pi \alpha \tau i$ ' $\alpha$ eindeutig die konsulare Gewalt."

${ }^{27}$ Feissel and Gascou 1989, op. cit. (n. 26), 552-554; F. Millar, The Roman Near East 31 B.C.-A.D. 337 (Cambridge and London 1993), 155f. ("'holding the hypateia', an expression which seems to indicate his [i.e., Priscus'] overall command of the region."); and M. Peachin, Iudex vice Caesaris. Deputy Emperors and the Administration of Fustice during the Principate (Stuttgart 1996), 176f. ("it looks as though regular governors continued to function somehow simultaneously with, yet under the thumb of a supra-provincial rector Orientis").

${ }^{28}$ W. Eck, 'C. Iulius Octavius Volusenna Rogatianus. Statthalter einer kaiserlichen Provinz', Zeitschrift fuir Papyrologie und Epigraphik, 90 (1992), 201; Feissel and Gascou 1995, op. cit. (n. 26), 80-83; M. Christol, L'Empire romain du III siècle. Histoire politique 192-325 après 7.-C. (Paris 1997), 99f.; C. Badel and A. Béranger, L'Empire romain au III siècle après 7.-C. Textes et documents (Paris 1998), 190 and C. Körner, 'Ein neuer Papyrus zur römischen Verwaltung im Osten des Reiches under Kaiser Marcius Iulius Philippus Arabs (244-249 n. Chr.)', in U. Pfister and M. de Tribolet (eds.), Sozialdisziplinirung - Verfahren - Bürokraten. Entstehung und Entwicklung der modernen Verwaltung (Basel 1999), 291.

${ }^{29}$ Körner 2002, op. cit. (n. 8), 59.

${ }^{30}$ Peachin 1996, op. cit. (n. 8), 176 f. 
that he went on to govern the peoples in the East, and since it is papyrologically recorded that he also administered justice from Antiochia, the position of rector Orientis clearly empowered him to wield the supreme command in all matters military and civil throughout the lands across the Aegean. ${ }^{31}$ Priscus' position resembles that of Avidius Cassius to the extent that both men combined the command of a concrete province (Mesopotamia and Syria respectively) with the overall supervision of the other Eastern provinces. Like Marcus Aurelius before him, Philippus Arabs, too, was fully absorbed by the laborious wars on the Danube and affairs in Rome from 245. The main differences with the position of Avidius Cassius, however, are constituted by the facts that Priscus apparently owed his position exclusively to the Emperor, like the regular correctores, and that he never assumed senatorial rank. More importantly, however, all of this also means that Priscus' rectorship of the East was a genuine imperial office which carried real and wide responsibilities. ${ }^{32}$ As it clearly was Priscus task to supervise and safeguard the Eastern provinces on behalf of his brother rather than to restore law and order or carry through vast reorganizations, he was made rector, not corrector. This subtle though conspicuous distinction in title may also have served

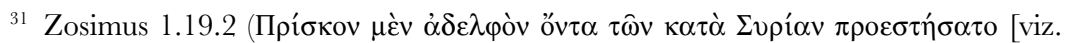

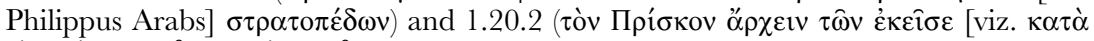

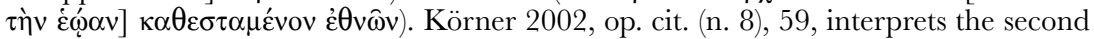
reference as indicating "dass Priscus mehrere Provinzen gleichzeitig verwaltete". His explanation of the first one, however, runs counter to his argument that Priscus assumed direct command of (among other provinces) Syria: "Diese Passage scheint zwar auf die syrische Statthalterschaft anzuspielen. Es ist jedoch wahrscheinlicher, dass Zosimos

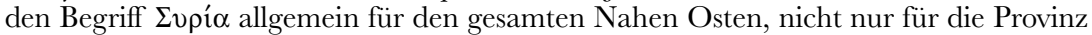
Syria Coele verwendet. Die Stelle umschreibt somit ebenfalls eine provinzenübergreifende Funktion." In my opinion, Peachin 1996, op. cit. (n. 27), 177, rightly suggests that "it looks as though regular governors continued to function somehow simultaneously with, yet under the thumb of a supra-provincial rector Orientis." In n. 94, Peachin further points to the fact that Claudius Capitolinus was praeses Arabiae in 245-246, i.e., during Priscus' tenure as rector Orientis.

32 Contra Körner 2002, op. cit. (n. 8), 54 who insists that the denomination of rector Orientis concerns "einen Titel, nicht...ein Amt"; cf. also p. 59: "Im Gegensatz zum corrector... handelte es sich um einem Titel, nicht um ein Amt." This view runs counter to Körner's own suggestions (55 and 57f.) that this title involved certain "Kompetenzen", and that "Zweifellos muss es sich dabei um eine wichtige Position im Osten des Reiches gehandelt haben". From the moment a title is not purely honorific and carries certain official prerogatives, it ipso facto also regards an office. Therefore, the distinction drawn by Körner is an artificial one. Besides, the enclitic - que in CIL 3.141495 = ILS 9005 (et praef. / praet. rect[o]riq. / Orientis) further suggests that, just like the praefectura praetoria, it concerns an office, not a mere title. 
to officially differentiate Priscus' extraordinary position from that of the regular imperial correctors. As there is no reason to believe that his supra-provincial command did not comprise proconsular Asia, one can, perhaps, speculate that Philippus Arabs also invested Priscus with consular imperium. ${ }^{33}$ It should, however, not be doubted that the Emperor officially instructed all regular officials in the East to heed Priscus' commands. ${ }^{34}$ On the basis of a reference in Zosimus, some scholars presume that under the reign of Aurelianus, one Marcellinus (ord. 275) also combined the offices of praefectus Mesopotamiae and rector Orientis. ${ }^{35}$

${ }^{33}$ During the discussion following the presentation of this paper, Professor W. Eck made the suggestion that Priscus held no imperium whatsoever since such matters had become irrelevant and all necessary arrangements were now made through imperial codicilla. That regular correctors and curators held imperium pro praetore is clear from, e.g., ILS $8826=$ IGRR 3.174 (Ancyra), where one C. Iulius Severus is attested as having been "sent with five fasces to Bithynia as corrector and curator by the deified Hadrian." As imperial legati pro praetore also carried five fasces, it should not be doubted that Severus (and all other correctors and curators) also held praetorium imperium. In my opinion, a couple of interesting references in the Historia Augusta (Scriptores Historiae Augustae, Vita Aemiliani 22.10 (fasces consulares) and Vita Probi 13.1) further suggest that Iulius Priscus, too, must have held some kind of imperium as rector Orientis, if only for tradition's sake.

${ }^{34}$ Unfortunately, the dearth of source material makes it impossible to establish whether or not the Senate was involved. If so, its role was probably limited to raising Priscus' delegated imperium to a consular level.

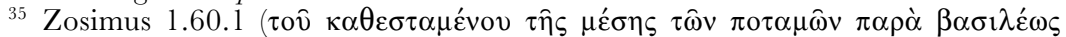

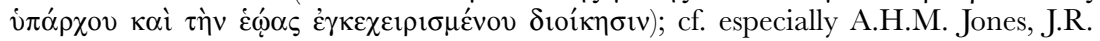
Martindale and J. Morris, The Prosopography of the Later Roman Empire 1 (Cambridge 1971), 544 (Marcellinus I): "His title would appear to have been praefectus Mesopotamiae rectorque Orientis". Contra Potter 1996, op. cit. (n. 1), especially 274 and 281, who compares the command of Odaenathus with that of, for example, Avidius Cassius and Iulius Priscus, Körner 2002, op. cit. (n. 8), 61, rightly explains that the position of Odaenathus fundamentally differed from that of Iulius Priscus and Marcellinus in that his successive appointments to the offices of dux Romanorum (in 262) and, perhaps, corrector totius Orientis (just one of several interpretations of CIS 2.3971, cf. Potter 1996, op. cit. (n. 1), 272) by Gallienus only formalized the position the Palmyrene king had already attained through his own efforts and victories over both Roman pretenders and Persians. For a recent discussion of Odaenathus' titulature and position in the East, see especially Potter 1996, op. cit. (n. 1). The command of Severianus in Moesia and

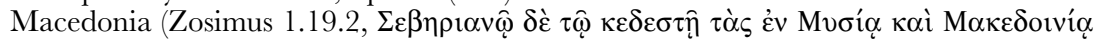

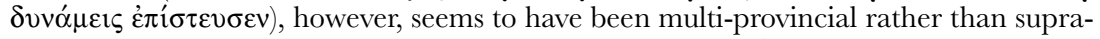
provincial; contra Potter 1996, op. cit. (n. 1), 278, where Severianus is listed in the category of "Governors with Supra-Provincial Imperium or Holders of Imperium Maius and Individuals Referred to as Commanders with Special Imperium for a War from Tiberius to Philip the Arab" (p. 277), with, among others, Avidius Cassius and Iulius Priscus; and Körner 2002, op. cit. (n. 8), 62f., who also seems to put the commands of Priscus and Severianus on a par. 


\section{General conclusions}

The nature of the extraordinary, supra-provincial commands of the late second and third centuries C.E. further highlights the general tendencies of this tempestuous age of transition. Unlike the extraordinary proconsuls of the Early Empire, who held independent imperium auspiciumque by virtue of statute law, it concerns imperial officials whose powers were (re)defined by the Emperor, and, if need be, the Senate. ${ }^{36}$ The commands of Pliny the Younger, Avidius Cassius and Iulius Priscus powerfully underscore the growing imperial preference for drastic and direct interfere in the administration of imperial and public provinces alike. ${ }^{37}$ In this respect, these commands are signal indicators of the erosion of the Augustan provincial arrangement and significant steps towards active and exclusive imperial control of the whole provincial dominion. This evolution also meant that the original distinction between governors of public and imperial provinces became increasingly meaningless, especially in the event of proconsuls being put under the command of imperial officials with derived, be it enhanced powers and status. Therefore, Probus' decision to invest all praesides or governors with the ius praetorium, the praetorium imperium, ${ }^{38}$ was nothing but the logical conclusion of a process in which the proconsulate evolved into a largely honorific and purely civil office. The supra-provincial commands of this age also further demonstrate the rise of the equestrian order. Whereas Pliny still passed through a normal senatorial career, Avidius Cassius was adlected inter quaestorios and Iulius Priscus maintained his

${ }^{36}$ Cf. P. Eich, Zur Metamorphose des politischen Systems Roms in der Kaiserzeit. Die Entstehung einer "personalen Bürokratie" im langen dritten Fahrhundert (Berlin 2005), 359, "In der ersten Phase des Prinzipates folgte man bei der Ausgestaltung dieser großräumige Einsatzbereiche noch republikanischen Vorbildern und erließ wohl entsprechende leges. Im zweiten und dritten Jahrhundert sind solche Prozeduren nicht mehr belegt und vermutlich auch nicht mehr in Anwendung gekommen." Eich's (p. 359 n. 4) suggestion that Corbulo's command, too, was constituted by law, however, is wrong altogether. Popular votes were only required if the extraordinary commander was to hold independent imperium auspiciumque.

${ }^{37}$ Cf. Eich 2005, op. cit. (n. 36), 360, "Besonders seit Marcus läßt sich eine Neigung der Zentrale erkennen, Provinzkomplexe einzelnen Amtsträgern längerfristig zu unterstellen." For a plausible explanation of why the Emperor and his counsels found it increasingly necessary to submit a well-defined number of regular provincial governors to supra-provincial imperial agents, see also Eich 2005, op. cit. (n. 36), 360.

38 This must be the scope of one of Probus' reforms summarized in Scriptores Historiae Augustae, Vita Probi 13: permisit patribus ut...proconsules crearent, legatos proconsulibus darent, ius praetorium praesidibus darent. 
equestrian status even after the accession of his brother and his own rise to unprecedented power. ${ }^{39}$ Last but not least, the reappearance of the supra-provincial commands from the late second century C.E. was an official acknowledgment of the fact that in case of serious internal or external crises, the administration of Empire simply required this kind of overarching commands. ${ }^{40}$ The Tetrarchy, then, can be construed as an ultimately unsuccessful attempt to reintroduce the early imperial system of 'vice-regents', be it on a structural and systematic basis and within the framework of radically reorganized imperial and administrative institutions. ${ }^{41}$

Ghent, June 2006

${ }^{39}$ Körner 2002, op. cit. (n. 8), 57.

${ }^{40}$ The revolt of Avidius Cassius, however, immediately revealed the inherent danger of such arrangements.

${ }^{41}$ Compare also Potter 1996, op. cit. (n. 1) 271, "Diocletian's decision to create a college of Augusti and Caesares stands at the end of a long history of power sharing that was defined in different ways." Eich 2005, op. cit. (n. 36), 359 rightly observes that the "supraprovinzialer Kommanden" of the third century C.E. were "Vorläufer der mehrstufigen spätantiken Provinzialadministration." 